九州大学学術情報リポジトリ

Kyushu University Institutional Repository

\title{
Cytotoxic Factor from Mouse Liver
}

Okamoto, Keiko

Laboratory of Pesticide Chemistry, Faculty of Agriculture, Kyushu University

Maekawa, Kazuyuki

Laboratory of Pesticide Chemistry, Faculty of Agriculture, Kyushu University

Eto, Morifusa

Laboratory of Pesticide Chemistry, Faculty of Agriculture, Kyushu University

https://doi.org/10.5109/23821

出版情報：九州大学大学院農学研究院紀要. 30 (2/3)，pp. 159-166，1985-12. Kyushu University バージョン：

権利関係 : 
J. Fac. Agr., Kyushu Univ., 30 (2 • 3), 159-166 (1985)

\title{
Cytotoxic Factor from Mouse Liver
}

\author{
Keiko Okamoto, Kazuyuki Maekawa \\ and Morifusa Eto \\ Laboratory of Pesticide Chemistry, Faculty of Agriculture, \\ Kyushu University 46-02, Fukuoka 812 \\ (Received September 2.5, 1985)
}

\begin{abstract}
An extract from mouse livers showed cytotoxic activity against Ehrlich ascites tumor cells. The activity was associated neither with proteins nor nucleotides in the extract. The active substance was heat-stable and appeared as a lipid, being extractable with organic solvents. It was slowly adsorbed to the cells during incubation to exert the cytotoxicity. The adsorption was inhibited in the presence of glucose.
\end{abstract}

\section{INTRODUCTION}

The presence of cytotoxic substances has been found in normal and tumor tissues of animals. Some of them may relate to tumor resistance in host animals. They include proteinous lymphotoxins from sensitized lymphoid cells (Granger et al., 1973; Peter et al, 1973; Williams and Granger, 1968), unknown substances to cause cachexia in patients bearing cancer (DeWys, 1970) and hepatic chalones (Thornley and Lawrence, 1975; Verly et al., 1971). A probable biogenetic amine from normal tissues has been known to suppress the growth of $\mathrm{L}$ cells by inhibiting protein synthesis (Bormer, 1976). Another low molecular weight compound from liver has been reported to inhibit the DNA synthesis of hepatoma cells (Sekas and Cook, 1976). On the other hand, subcellular fractions from Iiver phagocytic cells of mice inoculated with BCG have been studied to find a fraction which causes the lysis of tumor-cells (Ferluga and Allison, 1975).

In previous papers, we have reported the presence and the mode of action of a proteinous cytotoxic substance in the microsomal fraction of mouse spleen (Momii, et al., $1979 \mathrm{a}, \mathrm{b}$ ). Finding further a cytotoxic activity in the extract of normal mouse liver, we report some properties of the cytotoxic factor in this paper. In contrast with the spleen factor, the liver factor appears as a lipid.

\section{EXPERIMENTAL}

\section{Cytotoxicity test}

The cytotoxicity was defined as injurious change in the permeability of cell membrane and was assayed by dyeing the Ehrlich ascites tumor cells (E- 
cells) with nigrosine. E-cells harvested from ddN or ddd female mice were washed with a $\mathrm{Ca}^{2+}, \mathrm{Mg}^{2+}$-free phosphate-buffered saline solution (PBS(-)) or a $50 \mathrm{mM}$ Tris-HCl buffer solution and were suspended in the same solution to adjust the cell density as $1.3 \times 10^{8} \mathrm{cell} / \mathrm{s} / \mathrm{ml}$. A test sample $(0.5 \mathrm{ml})$ and the cell suspension $(0.01 \mathrm{ml})$ were mixed in a $10 \cdot \mathrm{ml}$ test tube and were incubated at $37^{\circ} \mathrm{C}$ with shaking. The test samples were always dissolved in and dialyzed, if necessary, against the same solution as that the cells were suspended. After $2 \mathrm{hr}$ incubation $1.5 \mathrm{ml}$ of saline containing $0.4 \%$ nigrosine was added to the mixture and cell number was counted on a hematometer. In order to correct possible errors owing to the autolysis of dead cells, the injured cell number (\%) was calculated as follows:

$$
\text { Injured cells }(\%)=100\left(L_{c}-L_{t} \times T_{c} / T_{t}\right) L_{c}
$$

where $\boldsymbol{L}$ and $\boldsymbol{T}$ denote the unstained (living) and total cell numbers, and the suffixes $\mathrm{c}$ and $t$ mean control and test, respectively. In the control the test sample was replaced with PBS(-) or the buffer solution. The experiment was duplicated.

The specific activity was represented as the reciprocal of absorbance at $280 \mathrm{~nm}\left(S A_{280}\right)$, or of weight $(\mathrm{mg})$ per $\mathrm{ml}(S A$,$) , of the test sample to injure$ $50 \%$ of the cells.

\section{Preparation of mouse liver extracts}

Livers from ddN female mice were sliced and homogenized in PBS(-) with a teflon homogenizer. To a 10, OOOxg supernatant obtained from the homogenate was added a saturated ammonium sulfate solution (30 \% saturation) and the resulting precipitate was dialyzed against PBS(-) by using a Visking tube to get a fraction, "Liver-30".

Liver-30 was treated for $30 \mathrm{~min}$ with a $59 \mathrm{mM}$ Tris-HCl buffer containing $500 \mathrm{mM} \mathrm{KCI}, 5 \mathrm{mM} \mathrm{MgCl}{ }_{2}$ and $0.18 \%$ sodium deoxycholate. The mixture was centrifuged at 105, OOOxg for $60 \mathrm{~min}$ and the supernatant was submitted to a Sephadex G-25 column $(2.6 \times 51.7 \mathrm{~cm})$ which had been equilibrated with PBS $(-)$. The UV absorbing fractions eluted with PBS(-) were pooled and backdialyzed against solid ammonium sulfate to make precipitation. The precipitate was dissolved in and dialyzed against PBS(-) for the cytotoxicity assay.

\section{Lipid extraction}

The microsome fraction of mouse liver homogenate was obtained by a usual manner at 100, OOOxg. To the microsome suspension in PBS(-) was added saturated ammonium sulfate to make $30 \%$ saturation. The precipitate, "Microsome-30", was dialyzed against PBS(-) for the assay.

The dialyzed microsome- was lyophilized and extracted with a chloroform-methanol $(1: 2)$ mixture at $4^{\circ} \mathrm{C}$ with shaking for 60 min according to Bligh-Dyer's method (Fujino, 1978). The insoluble materials were again extracted with a chloroform-methanol-water (1:2:0.8) mixture. The combined extracts were mixed with chloroform and water and the chloroform layer was separated. 


\section{Extraction of cytotoxic factor}

Mouse livers $(77.4 \mathrm{~g})$ were homogenized in $154.8 \mathrm{ml}$ of acetone in a homogenizer (Teraoka, type D) and filtered. The acetone was removed with a rotary evaporator under reduced pressure to get a residue (Acetone extract). The acetone extract was dissolved in benzene and fractionated with $2 \%$ tartaric acid and $2 \%$ sodium bicarbonate into basic, acid and neutral fractions according to a usual manner.

\section{Time course of cytotoxic action}

The reaction mixtures of Microsome- $\left(A_{280}=0.92\right)$ and E-cells $\left(1.3 \times 10^{6}\right)$ in PBS(-) were incubated at $37^{\circ} \mathrm{C}$ for 30,60 and 120 min, respectively. After the incubation, dead cells were counted.

\section{Adsorption of the cytotoxic factor on E-cells}

The concentrations of Microsome- in PBS(-) were adjusted to 1.12 , 3.37 and 37.3 in absorbance at $280 \mathrm{~nm}$. E-cells $\left(3 \times 10^{\prime \prime}\right)$ killed by heating at $80^{\circ} \mathrm{C}$ were added to $1.5 \mathrm{ml}$ of the Microsome- solutions. The mixtures were incubated at $37^{\circ} \mathrm{C}$ for $60 \mathrm{~min}$ and centrifuged. The supernatant was subjected to the cytotoxicity test.

\section{Inhibition of cytotoxic action with glucose}

The mixture of Microsome- $\left(A_{280}=1.12\right)$ and n-glucose in PBS(-) was assayed for the cytotoxicity.

For the time course study of interaction among glucose, the cytotoxic factor and E-cells, $0.25 \mathrm{ml}$ of $6.7 \mathrm{mM}$ glucose was added to the mixture of Microsome-30 $\left(A_{280}=1.94 ; 0.25 \mathrm{ml}\right)$ and E-cell suspension $(0.01 \mathrm{ml})$ which had been incubated at $37^{\circ} \mathrm{C}$ for an appropriate time. After incubation for $120 \mathrm{~min}$ in total, dead cells were counted.

\section{RESULTS AND DISCUSSION}

\section{Cytotoxicity of liver fractions}

Living cells were not dyed with nigrosine. Cells whose cell membrane was damaged by the action of a toxic substance incorporate the dye and the dyed cells then lyse. Thus, "dyed cell" is regarded as a synonym for "dead cell" in this paper.

The $10,000 \times g$ supernatant of mouse liver extract with PBS(-) showed such a cytotoxic activity against Ehrlich ascites tumor cells; the specific activity based on $A_{280}\left(S A_{280}\right)$ was 1.1. Ammonium sulfate precipitated the cytotoxic factor at $30 \%$ saturation, giving the fraction "Liver-30" $\left(S A_{280}=2.3\right)$. The precipitate of Liver-30 at 105,000 $\times g$ (microsomal fraction) had an $S A_{280}$ of 3.4 but the solublized fraction obtained by treating it with deoxycholate was inactive.

On the other hand, the chloroform-methanol extract of mouse liver microsomes (Microsome-30), whose specific activity based on $\mathrm{mg} / \mathrm{ml}(\mathbf{S A}$,$) was 2.1,$ showed a high cytotoxicity $\left(S A_{w}=17.5\right)$, suggesting that the cytotoxic factor 
is a kind of microsomal lipids.

Since preparing the microsomal fraction is unsuitable to obtain mass of the cytotoxic substance, we examined to extract it directly from the liver. Direct extraction with a chloroform-methanol mixture according to Wada and Sugano (1972) and Kates (1972) was unsuccessful, while the acetone was effective to extract the cytotoxic factor from livers.

The acetone extract was fractionated into acid, basic and neutral fractions. Only the neutral fraction had the cytotoxic activity (Table 1). Its specific activity $\left(S A_{w}=18.5\right)$ is comparable to that of the chloroform-methanol extract of the microsomes. The total activity found in the neutral fraction was 9 times as much as that in the acetone extract, suggesting that some inhibitory substances may be removed by treating with acid and base.

Table 1. Fractionation of mouse liver cytotoxic factor.

\begin{tabular}{cccc}
\hline Fraction & Yield & Specific activity & Total activity \\
\hline Acetone extract & $(\mathrm{g})$ & 0.54 & 5.6 \\
Neutral fraction & 10.4 & 18.5 & 49.9 \\
\hline
\end{tabular}

1) Reciprocal of $\mathrm{mg} / \mathrm{ml}$ to kill $50 \%$ of cells.

\section{Properties of the mouse liver cytotoxic factor}

Since the cytotoxic factor found from mouse spleen was sensitive to protease to lose the cytotoxicity (Momii et al., $1979 \mathrm{a}, \mathrm{b}$ ), we examined the effects of some enzymes against the present liver cytotoxic factor, using Liver-30. When it was incubated with a non-specific protease from Streptomyces griseus (pronase, Sigma Chemical Co.) or nuclease $\mathrm{P}_{1}$ at $37^{\circ} \mathrm{C}$ for $60 \mathrm{~min}$, no cytotoxic activity was lost (Table 2). Thus, neither protein nor nucleic acids may associate with the cytotoxicity of the liver factor.

The thermostability of Liver-30 was also tested. The specific activity increased a little by heat treatments; it did 1.1 and 1.56 times by heating at 60 and $100^{\circ} \mathrm{C}$, respectively, for $30 \mathrm{~min}$. When Liver-30 heated at $100^{\circ} \mathrm{C}$ was dialyzed against PBS(-) for $9 \mathrm{hr}$, the cytotoxic activity did not change owing probably to the insolubility of the factor in aqueous media. From these findings and the results of extraction with organic solvents, it was concluded that the liver-cytotoxic factor should be a lipid.

Table 2. Effects of heat and enzymes on cytotoxic activity.

\begin{tabular}{|c|c|c|}
\hline Sample & Treatment with & Specific activity' \\
\hline Liver-30 & none & 1. 2 \\
\hline Liver-30 & heating ${ }^{2}$ & 1.5 \\
\hline Heated Liver-30 & pronase & 1.9 \\
\hline Liver-30 & nuclease $P_{1}$ & 1.9 \\
\hline
\end{tabular}

1) Reciprocal of absorbance at $280 \mathrm{~nm}$ to kill $50 \%$ of cells.

2) Heated at $100^{\circ} \mathrm{C}$ for $30 \mathrm{~min}$, the sample was centrifuged to get the supernatant (heated Liver-30) for cytotoxicity assay. 
This liver cytotoxic factor is apparently different from the proteinous cytotoxic factor of mouse spleen (Momii et al., $1979 \mathrm{~b}$ ) and also from hepatic chalon which is labile to proteinase (Thornley and Laurence, 1975). Barra et al (1979) found water-soluble cytotoxic factors from liver which consisted of thermo-labile biopolymer and stable factor. The latter looks similar to the present cytotoxic factor, but they differ each other in the point of water-solubility.

Ferluga and Allison (1975) have reported that plasma membrane from lymphoid cell systems has cytotoxic activity to cause the lysis of cells, provided the cell contacts with the membrane, indicating the importance of plasma membrane for immunological response. It is interesting in this context to note that the present cytotoxic factor active against E-cells was obtained from the microsomal fraction, a kind of plasma membranes, of normal liver cells.

\section{M ode of action}

A time course study in the cytotoxic action of Microsome- showed a lag time of about 30 min (Fig. 1). This may be explained if the slowly adsorbed factor triggers a prompt cell-damage as soon as exceeding a threshold of adsorption on the cell. The cytotoxic factor was actually adsorbed to E-cells, even after killed by heat. The amount of the factor (Microsome-30; $A_{280}=$ ca. 1) corresponding to kill $100 \%$ of E-cells assayed was completely lost by adsorption to $3 \times 10^{6}$ cells which had been killed by heat (Fig. 2).

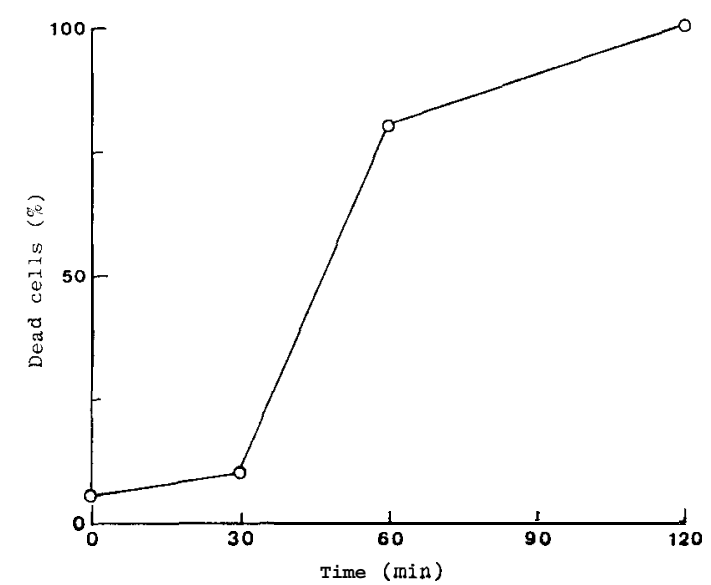

Fig. 1. Time course for the cytotoxic action of Microsome- at $37^{\circ} \mathrm{C}$.

The cytotoxic activity of Microsome- was inhibited in the presence of glucose, provided that glucose and the cytotoxic factor were simultaneously mixed with E-cells (Fig. 3). The inhibition was complete at $3.3 \mathrm{mM}$ of glucose for Microsome- whose absorbance at $280 \mathrm{~nm}$ was 1.12 . The cytotoxicity of Microsome- at this concentration was $100 \%$ in the absence of glucose. 


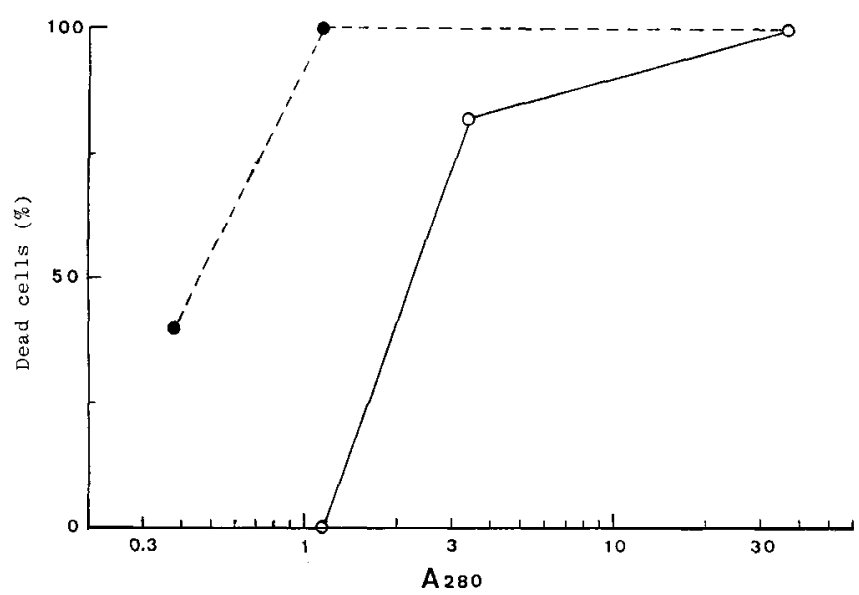

Fig. 2. Adsorption of cytotoxic factor to E-cells.

$\mathrm{O}-\mathrm{O}$ : After Microsome- was incubated with E-cells killed by heating for $60 \mathrm{~min}$, the cells were spun down and the supernatant was assayed for cytotoxicity. $A_{280}$ indicates the values before treating for the adsorption. : Control.

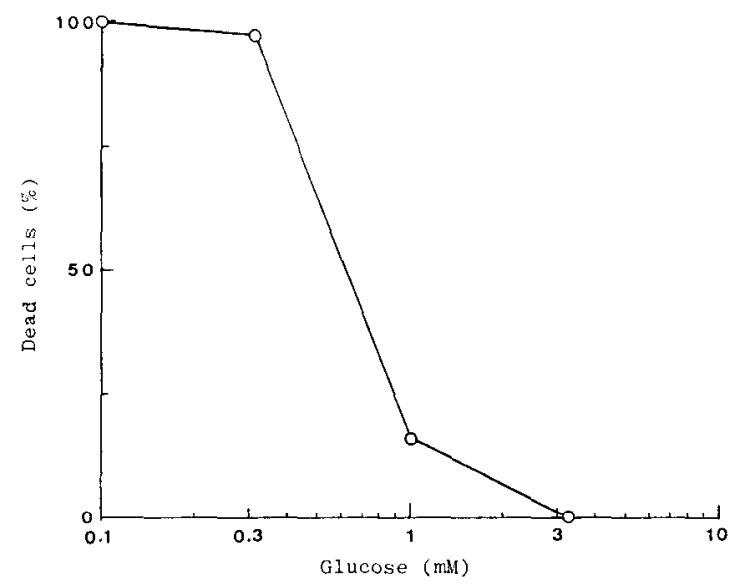

Fig. 3. Inhibition of cytotoxic activity with glucose.

The concentration of Microsome- used $\left(A_{280}=1.12\right)$ was enough to kill $100 \%$ of E-cells in the absence of glucose.

When E-cells had been preincubated with the factor before adding glucose $(3.3 \mathrm{mM})$, the inhibitory activity of glucose was seen by $30 \mathrm{~min}$ preincubation, whereas any effect of glucose was not observed in preincubation longer than 60 min (Fig. 4).

Tumor cells are known to have a great affinity for glucose (Shapot, 1972). It may inhibit the adsorption of the cytotoxic factor to the cells but can not rescue the cell-damage affected by the adsorbed cytotoxic factor. 


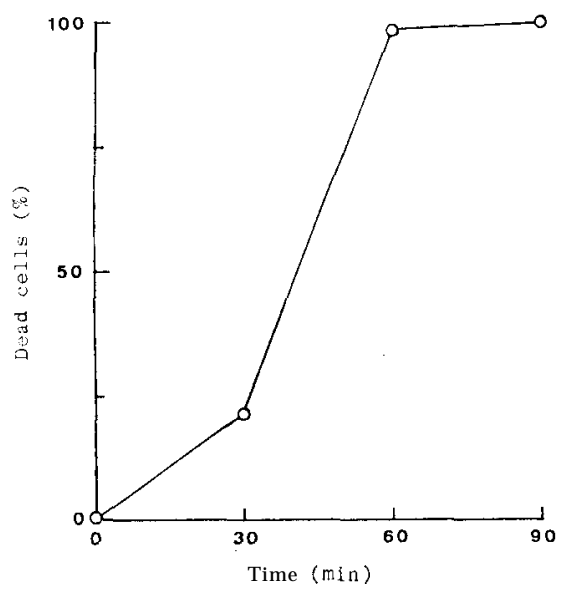

Fig. 4. Time course for the inhibitory action of glucose on the cytotoxic activity of Microsome-30.

The abscissa indicates preincubation time before addition of glucose ( 3.3 $\mathrm{mM})$. The ordinate indicates the cytotoxic activity of Microsome- $\left(A_{280}=\right.$ $0.98)$.

\section{ACKNOWLEDGMENTS}

This work was partially supported by a Grant-in-Aid for Scientific Research from the Ministry of Education, Science and Culture of Japau.

\section{REFERENCES}

Barra, K., J. Parsons, M. R. Koch and M. A. Lea 1979 Soluble factors from liver and hepatomas which inhibit $\left[{ }^{3} \mathrm{H}\right]$ thymidine incorporation into DNA of Novikoff hepatoma cells. Cancer Res., 39: 1655-1660

Bormer, 0. P. 1976 Purification of a cytotoxic factor from human and rat tissues. Br. J. Cancer. 34: 359-367

DeWys, W. 1970 Working conference on anorexia and cachexia of neoplastic disease. Cancer Res., 30: 2816-2818

Ferluga, J. and A. C. Allison 1975 Cytotoxicity of isolated plasma membranes from lymph node cells. Nature, 255: 708-710

Fujino, Y. 1978 Shishitsu Bunsekiho Nyumon, Gakkai Shuppan Center, Tokyo, p. 43

Granger, G. A., E. C. Laserna, W. P. Kolb and F. Chapman 1973 Human lymphotoxin: purification and some properties. Proc. Nat. Acad. Sci., 70: 27-30

Kates, M. 1972 Techniques of Lipidology, ed. by T. S. Work and E. Work, North-Holland, Amsterdam, p. 347-353

Momii, A., T. Inenaga, K. Maekawa and M. Eto 1979a Mode of action of a cytotoxic factor in mouse spleen. J.Fac.Agr., Kyushu Univ., 24: 93-100

Momii, A., K. Maekawa and M. Eto 1979b A cytotoxic subcellular fraction of mouse spleen extract. J. Fac. Agr., Kyushu Univ., 24: 81-92

Peter, J. B., J. A. Stratton, K. E. Stempel, D. Yu and C. Cardin 1973 Characteristics of a cytotoxin ("lymphotoxin") produced by stimulation of human lymphoid tissue. $J$. 
Immunol., 111: 7-m-182

Sekas, G. and R. T. Cook 1976 The isolation of a low molecular weight inhibitor of $\left[{ }^{3} \mathrm{H}\right] \mathrm{TdR}$ incorporation into hepatic DNA. Exp. Cell Res., 102: 422-425

Shapot, V. S. 1972 Some biochemical aspects of the relationship between the tumor and the host. Adv. Cancer Res., 15: 253-286

Thornley, A. L. and E. D. Lawrence 1975 The present state of biochemical research on chalones. Int.J. Biochem., 6: 313-320

Verly, Q. G., Y. Deschamps, J. Pushpathadam and M. Desrosiers 1971 The hepatic chalone, I. Assay method for the hormone and purification of the rabbit liver chalone. Can. J. Biochem., 49: 1376-1383

Wada, M. and M. Sugano 1972 The practical methods for utilization of thin-layer chromatography to the analysis of glycerolipids from animal tissues. Sci. Bull. Fac.Agr., Kyushu Univ., 26: 505-516

Williams, T. W. and G. A. Granger 1968 Lymphocyte in vitro cytotoxicity: Lymphotoxins of several mammalian species. Nature, 219: 1076-1977 